\title{
FSH and testosterone signaling in Sertoli cells
}

\author{
William H Walker and Jing Cheng \\ Department of Cell Biology and Physiology, University of Pittsburgh, Pittsburgh, PA 15261, USA
}

Correspondence should be addressed to W H Walker; Email: walkerw@pitt.edu

\begin{abstract}
Testosterone and follicle-stimulating hormone (FSH) are required to obtain full reproductive potential. In the testis, somatic Sertoli cells transduce signals from testosterone and FSH into the production of factors that are required by germ cells as they mature into spermatozoa. Recent advances in identifying new signaling pathways that are regulated by FSH and testosterone have allowed for refinement in the understanding of the independent, overlapping and synergistic actions of these hormones. In this review, we discuss the signaling pathways that are regulated by FSH and testosterone as well as the resulting metabolic and gene expression changes that occur as related to Sertoli cell proliferation, differentiation and the support of spermatogenesis.
\end{abstract}

Reproduction (2005) 130 15-28

\section{Introduction}

Male fertility and the process of spermatogenesis are dependent upon the somatic Sertoli cells to produce factors that are required by developing germ cells (reviewed in Sharpe 1994, Griswold 1998). The number of Sertoli cells determines testicular size, germ cell numbers per testis and spermatozoa output (Orth et al. 1988). Furthermore, Sertoli cells provide a specialized, protected environment within the seminiferous tubules of the testis for germ cell development. Adjacent Sertoli cells form tight junctions with each other such that nothing larger than 1000 daltons can pass from the outside to the inside of the tubule. This characteristic of Sertoli cells creates what is known as the blood-testis barrier. At the beginning of meiosis, germ cells located outside of the barrier pass through the tight junctions. Once beyond the blood-testis barrier, germ cells are dependent on Sertoli cells to supply nutrients and growth factors (reviewed in Mruk \& Cheng 2004). Sertoli cells provide factors required to fuel germ cell metabolism (lactate, transferrin, androgen binding protein), growth regulatory factors (stem cell factor, transforming growth factors alpha and beta (TGF- $\alpha$ and TGF- $\beta$ ), insulin-like growth factor-I (IGF-I), fibroblast growth factor (FGF) and epidermal growth factor (EGF) and hormones that regulate the development of the male reproductive structures or feedback to regulate the hormonal signals affecting Sertoli cells (mullerian-inhibiting substance (MIS), and inhibin) (reviewed in Skinner 2005).

The process of spermatogenesis is regulated by a complex interplay of endocrine and paracrine signals. The master control hormone is gonadotropin releasing hormone $(\mathrm{GnRH})$, a decapeptide produced by specialized neurons in the hypothalamus. Pulsatile GnRH production signals gonadotroph cells in the anterior pituitary to produce follicle-stimulating hormone (FSH) and luteinizing hormone $(\mathrm{LH})$ that then act on the testis to regulate spermatogenic potential. LH binds to receptors on the surface of Leydig cells in the testis and stimulates the production of testosterone, a steroid hormone that diffuses into the seminiferous tubules. Within the seminiferous tubules only Sertoli cells possess receptors for testosterone and FSH and thus these cells are the major targets of the ultimate hormonal signals that regulate spermatogenesis. In this review, we discuss the molecular mechanisms by which the FSH and testosterone signals that are required to support spermatogenesis are transduced and integrated in Sertoli cells.

\section{FSH signaling mechanisms}

\section{FSH binding to the FSH receptor}

FSH is a member of the glycoprotein hormone family that includes LH, human chorionic gonadotropin and thyroidstimulating hormone. These hormones are disulfide-rich heterodimers that share a common $\alpha$ subunit but have unique $\beta$ subunits that impart hormone specificity. FSH transmits its signals via the $75 \mathrm{kDa} F S H$ receptor $(675$ amino acids). The FSH receptor is a G protein-coupled receptor that spans the membrane seven times with seven conserved alpha helixes (reviewed in Simoni et al. 1997, 
Heckert \& Griswold 2002). The gene encoding the FSH receptor consists of 10 exons. The first 9 exons encode the extracellular domain and the last exon encodes the membrane-spanning region. The crystal structure of $\mathrm{FSH}$ bound to the hormone-binding domain of the FSH receptor has been solved to reveal that FSH and its receptor interact in a manner that resembles a handclasp. Ten parallel $\beta$-strands of the receptor and additional loops just Cterminal to the $\beta$ stands surround and contact FSH. The receptor wraps around the middle section of the hormone, interacting with $\mathrm{C}$-terminal segments and other loops of both the $\mathrm{FSH}-\alpha$ and $\mathrm{FSH}-\beta$ subunits. When FSH interacts with the receptor, the hormone undergoes a series of conformational adjustments and adopts a rigid structure that appears to be required for signaling. As a result of hormone binding to the ectodomain of the receptor, structural changes occur in the seven membrane-spanning domain that illicit guanine nucleotide exchange in associated $\mathrm{G}_{\mathrm{s}}$ proteins. There is also evidence that ligand binding causes dimerization of plasma membrane FSH receptors through contacts that are limited to the cytoplasmic domains and that receptor dimerization contributes to signaling (Dias 2005, Fan \& Hendrickson 2005).

\section{Sertoli cell ontogeny and FSH signaling}

During the last four days of gestation (fetal days 17.5-21.5), plasma FSH levels in rats increase nearly 2 -fold to approximately $250 \mathrm{ng} / \mathrm{ml}$ at birth and then reach almost $400 \mathrm{ng} / \mathrm{ml}$ by 5 days of life. FSH levels in serum transiently peak at about $800 \mathrm{ng} / \mathrm{ml}$ by day 35 before reaching steady-state levels of $400 \mathrm{ng} / \mathrm{ml}$ in 50 day-old rats (Chowdhury \& Steinberger 1976, Ketelslegers et al. 1978). Low levels of FSH receptor activity in rat gonads can be detected after 14.5 days of gestation but FSH binding activity increases about four-fold over fetal days 19.5 to 21.5 (Warren et al. 1984). This increase in FSH receptors is concurrent with increased Sertoli cell proliferation. It is not clear whether the proliferation is dependent upon increased FSH receptor levels or whether the increased number of Sertoli cells accounts for the elevated FSH

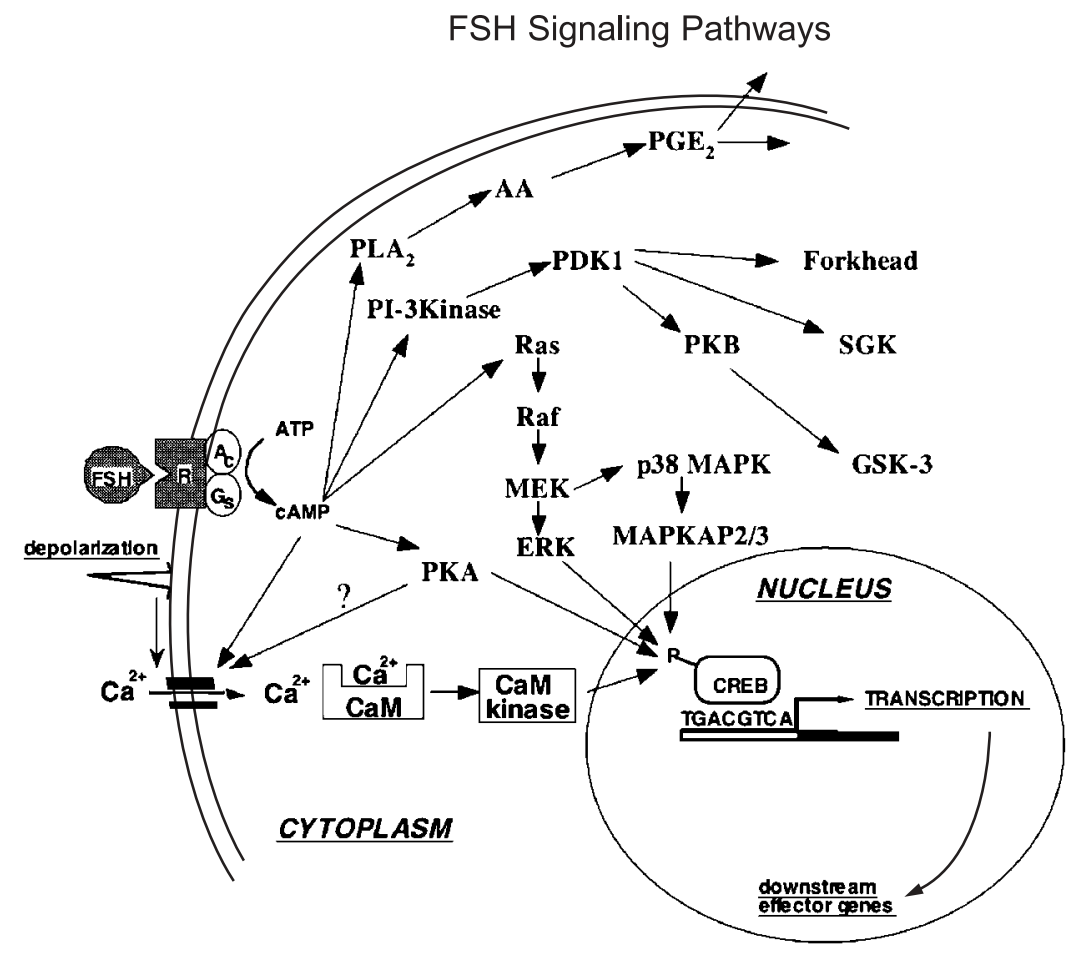

Figure 1 Signaling pathways activated by FSH are displayed. Initially FSH binding to the FSH receptor causes receptor coupled G proteins to activate adenylate cyclase (AC) and increase intracellular cAMP levels. Multiple factors can be activated by cAMP in Sertoli cells including PKA that can phosphorylate a number of proteins in the cell and also regulate the expression and activity of numerous transcription factors including CREB. FSH also causes $\mathrm{Ca}^{2+}$ influx into Sertoli cells that is mediated by cAMP and perhaps PKA modification of surface $\mathrm{Ca}^{2+}$ channels. Depolarization of the cell is also involved in $\mathrm{Ca}^{2+}$ influx. Elevated $\mathrm{Ca}^{2+}$ levels can activate calmodulin and CaM kinases that have multiple potential downstream effects including the phosphorylation of CREB. During puberty, FSH activates the MAP kinase cascade and ERK kinase in Sertoli cells most likely via cAMP interactions with guanine nucleotide exchange factors (GEFs) and activation of Ras-like G proteins. ERK is capable of activating transcription factors including SRF, c-jun and CREB. In granulosa cells, FSH also activates the p38 MAP kinase. FSH and cAMP also likely act through GEFs to activate PI3-K and then phosphoinositide dependant protein kinase (PDK1) and PKB in Sertoli cells. Studies of granulosa cells identified Forkhead transcription factor (Forkhead), SGK (glucocorticoid-induced kinase) and GSK-3 (glycogen synthase kinase-3) as additional downstream targets of the PI3-K pathway. FSH also mediates the induction of $\mathrm{PLA}_{2}$ and the subsequent release of arachadonic acid (AA) and the activation of eicosanoids such as $\mathrm{PGE}_{2}$ that may act as intracellular or extracellular signaling agents. 
binding activity that is detected. Ketelslegers and colleagues assayed FSH binding activity in testis extracts after birth and determined that by 2 days of life FSH receptors are approximately $40 \mathrm{fmol} /$ testis (Ketelslegers et al. 1978). FSH receptor numbers per testis then continually increase up to a plateau of $1000 \mathrm{fmol} /$ testis 60 days after birth. Studies by Bortolussi et al. resulted in similar trends but receptor concentrations were found to be 3 to 10-fold lower (Bortolussi et al. 1990). Both groups observed that after birth the concentration of receptors in the testis increases about 3-fold, peaking at 15 days after birth after which receptor levels fall in the adult to levels approximately that of the 2 day-old Sertoli cell. These changes in concentration reflect the increase in $\mathrm{FSH}$ receptors due to Sertoli cell proliferation 2 to 15 days after birth and the subsequent dilution of Sertoli cells due to the expansion of germ cells (Orth 1984, Meachem et al. 1996). The number of FSH receptors per Sertoli cell actually remain relatively constant from 2 to 21 days after birth (1500-1900 receptors/cell) but increase by another 2 -fold each by 40 days and again by 60 days after birth (Bortolussi et al. 1990).

\section{Cyclical regulation of the $\mathrm{FSH}$ receptor in the adult}

In the adult rat seminiferous tubules, spermatogenesis occurs in a cyclical fashion such that, within any one region of the tubule, spermatogonial stem cells divide approximately every 12 days. As a result, there are regular, defined associations of germ cells that develop and are replenished together in any one region. Each step of the development of the associated germ cells can be divided into stages that have defined physiological characteristics and cell associations (cell association stages I-XIV in rats). One cyclical characteristic that has been characterized is FSH-mediated production of cAMP in Sertoli cells. In the adult rat and human, serum FSH levels remain relatively constant. However, the expression of FSH receptors on Sertoli cells varies more than threefold in a cyclical and stage-specific manner such that receptor levels are highest in stages XIII-II and minimal during stages VII-VIII (Heckert \& Griswold 1991). The levels of FSH-induced cAMP production in Sertoli cells closely follows the levels of FSH receptor with highest levels of cAMP observed in stages XIV-VI (Kangasniemi et al. 1990).

$\mathrm{FSH}$ and intracellular CAMP are important regulators of $\mathrm{FSH}$ receptor levels in cultured Sertoli cells and in vivo. FSH stimulation results in a transient down-regulation of $\mathrm{FSH}$ receptor expression 4 to $8 \mathrm{~h}$ after addition of the hormone. By $16 \mathrm{~h}$, receptor mRNAs return to control values (Themmen et al. 1991, Maguire et al. 1997). The levels of $\mathrm{FSH}$ receptor are determined primarily by the activity of the $\mathrm{FSH}$ receptor gene promoter region. A major FSH-regulated element within the rat $\mathrm{FSH}$ receptor promoter is a regulatory motif matching the defined core sequence CANNTG called an E-box that is located $23 \mathrm{bp}$ upstream of the transcription start site. This E-box was shown to bind the helix-loop-helix transcription factors USF-1 and USF-2 (upstream stimulatory factor 1 and 2); activators of genes that support differentiation (Heckert et al. 1998). Interestingly, FSH and cAMP were recently shown to induce the expression of the Id 2 gene, a member of the inhibitor of differentiation family of gene regulators that repress E-box mediated transcription (Scobey et al. 2004). Overexpression of another Id protein (Id1) was shown to decrease $\mathrm{FSH}$ receptor promoter activity by up to $50 \%$ (Goetz et al. 1996). It remains to be determined whether $\mathrm{FSH}$-mediated induction of Id proteins is responsible for the cyclical down-regulation of the $\mathrm{FSH}$ receptor gene.

\section{FSH signal transduction pathways}

FSH binding to its receptor is known to activate at least 5 signaling pathways in Sertoli cells (Fig. 1). These pathways are discussed below.

\section{CAMP-PKA pathway}

In the first FSH-regulated pathway to be identified, the binding of $\mathrm{FSH}$ to its receptor catalyzes the exchange of GDP for GTP that leads to the disassociation of $G_{\alpha}$ and $G_{\beta \gamma}$. The GTP bound form of the $G_{\alpha}$ protein stimulates adenylate cyclase resulting in the production of cAMP (Zhang et al. 1991). Increased intracellular cAMP concentrations release the catalytic subunit of protein kinase $A$ (PKA) from repressor subunits allowing phosphorylation of numerous cellular proteins. One target for the increase in CAMP and PKA is a class of transcription factors that bind to cAMP response elements (CREs). Specifically, the CRE binding protein (CREB) transcription factor is rapidly activated after being phosphorylated on serine 133 by PKA in response to $\mathrm{FSH}$ stimulation (Walker et al. 1995). The importance of CREB phosphorylation for fertility was identified using in vivo studies in which a mutant CREB isoform that could not be phosphorylated was over expressed exclusively in Sertoli cells in rat testes. Testes receiving the mutant CREB displayed disrupted spermatogenesis in greater than $40 \%$ of the seminiferous tubules due to the apoptosis of spermatocytes and subsequent loss of more than $75 \%$ of spermatids (Scobey et al. 2001).

Once phosphorylated, CREB is able to activate transcription from the promoters of numerous genes. Two examples include the CREB gene promoter and an internal promoter within the highly homologous CREM gene that results in production of the inducible CAMP early repressor (ICER) repressor of CRE-mediated gene transcription (Molina et al. 1993, Walker et al. 1995). After being induced by CREB, ICER represses transcription from its own promoter and the CREB promoter (Molina et al. 1993, Walker et al. 1998). Transient down-regulation of CREB due to the expression of ICER prior to the auto-inhibition of ICER may explain the oscillating cAMP-mediated 
CREB mRNA expression that was observed in Sertoli cells during the spermatogenic cycle (Walker \& Habener 1996). FSH has also been implicated in the expression of various isoforms of CREM that are expressed in spermatoctyes and spermatid germ cells and are required for survival (Foulkes et al. 1993, Nantel et al. 1996). However, this regulation of germ cell CREM by FSH must be indirectly mediated through as yet unidentified Sertoli cell factors.

\section{MAP kinase pathway}

The MAP kinase cascade and ERK kinases are activated by $\mathrm{FSH}$ in cultured rat Sertoli cells following the dual coupling of the FSH receptor to $G_{s}$ and $G_{i}$ heterotrimeric proteins. The activation of ERK kinase is dependent on PKA and Src kinases although the exact signaling pathway has not been characterized. FSH activates ERK kinase in Sertoli cells cultured from 5 and 11 day-old rats but not 19 day-old rats (Crepieux et al. 2001). Thus, this FSH-regulated pathway may not play a large role in maintaining spermatogenesis or other processes in adult rats. However, it is significant that the timing of FSHmediated activation of the MAP kinase cascade is limited to the period of Sertoli cell proliferation that occurs in the first 15 days after birth because FSH stimulates Sertoli cell proliferation via this pathway. The FSH and ERK-dependent induction of cyclin D1 and E2F, two promoters of entry into the cell-cycle, also suggests that mitogenic effects of FSH are at least partly mediated by the MAP kinase cascade during puberty (Crepieux et al. 2001).

In contrast to cultured cells, Sertoli cells from 5 day-old rats placed into suspension had the opposite response to FSH. Under these conditions the gonadotropin repressed ERK activity via a CAMP dependent but PKA independent mechanism that required the activation of a tyrosine phosphatase (Crepieux et al. 2002). One clue toward understanding this mechanism for FSH-mediated inhibition of ERK activity in Sertoli cells has been provided by studies of granulosa cells that identified a $100 \mathrm{kDa}$ tyrosine phosphatase that binds to and maintains lower basal levels of ERK kinase activity. In granulosa cells, ERK kinase activity is only activated after FSHmediated phosphorylation of the phosphatase releases it from ERK (Cottom et al. 2003). It is possible that a similar tyrosine phosphatase may be utilized in Sertoli cells to limit the activation of ERK and downstream factors. Studies of granulosa cells also identified another MAP kinase, p38 kinase, as being induced by FSH, thus raising the possibility of p38 kinase regulation by FSH in Sertoli cells (Maizels et al. 1998).

\section{Calcium pathway}

FSH $(10-1000 \mathrm{ng} / \mathrm{ml})$ causes an increase in intracellular $\mathrm{Ca}^{2+}$ within seconds of stimulation (Grasso \& Reichert
1989, Gorczynska \& Handelsman 1991, Sharma et al. 1994, Lalevee et al. 1997). In freshly isolated Sertoli cells in suspension, FSH causes an influx of $\mathrm{Ca}^{2+}$ through the plasma membrane via both voltage gated and voltage independent calcium channels (Gorczynska \& Handelsman 1991). Sertoli cells in culture for two days respond to $\mathrm{FSH}$ with $\mathrm{Ca}^{2+}$ release from intracellular stores that then cause $\mathrm{Ca}^{2+}$ influx due to calcium releaseactivated current (Lalevee et al. 1997). In both cases it is thought that FSH-mediated elevation of intracellular $\mathrm{Ca}^{2+}$ is predominately due to increases in CAMP, and that PKA may contribute to alter channel activity (Gorczynska et al. 1994, Sharma et al. 1994, Lalevee et al. 1997). One result of increasing intracellular $\mathrm{Ca}^{2+}$ is the activation of calmodulin and CaM kinases that may affect cytoskeletal structure of Sertoli cells and phosphorylation of transcription factors including CREB (Spruill et al. 1983, Franchi \& Camatini 1985, Wu et al. 2001). In addition, $\mathrm{Ca}^{2+}$ likely plays an important role in Sertoli-Sertoli junction dynamics, although most studies showing the importance of $\mathrm{Ca}^{2+}$ in tight junction dynamics have been performed in other cell types (Franchi \& Camatini 1985, Mruk \& Cheng 2004).

\section{Phosphatidylinositol 3-kinase (PI3-K) pathway}

FSH was first found in granulosa cells to activate phosphatidylinositol 3-kinase (PI3-K) that generates specific inositol phospholipids that are bound by and activate protein kinase B encoded by the akt gene (PKB/akt) (GonzalezRobayna et al. 2000). More recently, FSH was also found to activate PKB in a PI3-K-dependent manner in Sertoli cells (Meroni et al. 2002). The most favored mechanism for PI3-K activation is via FSH-mediated increases in CAMP levels. Using inhibitors of PI3-K, it was shown that $\mathrm{FSH}$ acting through $\mathrm{PI} 3-\mathrm{K}$ contributes to metabolic processes required to support germ cells. Specifically, PI3-K inhibitors reduced the ability of $\mathrm{FSH}$ to induce the activity of lactate dehydrogenase (LDH) required to produce lactate for germ cells and $\gamma$-glutamyl transpeptidase $(\gamma$-GTP) a transporter of amino acids across the plasma membrane. Also dependent on PI3-K is the uptake of glucose that is converted to lactate for the germ cell energy needs and transferrin secretion that is vital for maintenance of spermatogenesis (Meroni et al. 2002). The seven membranespanning domain of the FSH receptor has been found to interact with the protein APPL (adapter protein containing $\mathrm{PH}$ domain, PTB domain and leucine zipper motif) that in turn interacts with the $\mathrm{p} 110 \alpha$ catalytic subunit of PI3-K and with inactive PKB/akt (Nechamen et al. 2004). This juxtapositioning of signaling factors likely potentiates FSH activation of PI3-K mediated events.

\section{Phospholipase $A_{2}\left(P L A_{2}\right)$ pathway}

$\mathrm{FSH}$ through the activation of phospholipase $\mathrm{A}_{2}\left(\mathrm{PLA}_{2}\right)$ leads to the release of the arachadonic acid second messenger and its subsequent metabolism to prostoglandin $E_{2}$ 
and other eicosanoids that function as intracellular and extracellular signals. As a result, adenylate cyclase activity and androgen aromatization are stimulated in Sertoli cells and germ cells may be affected via their G-protein coupled eicosanoid receptors (Jannini et al. 1994). Further studies will be required to better characterize the downstream factors that are affected by $\mathrm{FSH}$ activation of the $\mathrm{PLA}_{2}$ pathway.

Because FSH can activate at least 5 signaling pathways in Sertoli cells it might be expected that some crosstalk occurs to organize the final desired cellular consequences. Although potential crosstalk has not been extensively studied, it has been proposed that oligomerization of FSH receptors may provide a mechanism bringing together the components of multiple signaling pathways (PKA, PI3-K, PKB/akt and $\mathrm{PLA}_{2}$ ) to refine and control intracellular signaling (Nechamen et al. 2004). It should be noted that much of the valuable progress made toward characterizing FSH signaling has been performed with immature Sertoli cells. Further work will be necessary using fully differentiated Sertoli cells to understand the activation of these pathways and their roles in supporting spermatogenesis in adults.

\section{Desensitization of the $\mathrm{FSH}$ receptor}

Prolonged exposure of target cells to $\mathrm{FSH}$ results in a decreased response with time (desensitization). For example, a two-hour pretreatment with FSH reduces a subsequent $\mathrm{FSH}$-mediated induction of CAMP production by $70 \%$ or more (Verhoeven et al. 1980, Troispoux et al. 1999). Desensitization can initiate within minutes of $\mathrm{FSH}$ binding to the FSH receptor. In this process, the receptor is phosphorylated on the first and third intracellular loops by $\mathrm{G}$ protein-coupled receptor kinases that allows arrestin proteins to bind to the intracellular domain of the receptor, thereby uncoupling the receptors from $G$ proteins and preventing further signal transduction. Arrestins also facilitate internalization of receptors by interacting with clathrin and concentrating receptors in clathrin coated pits (Nakamura et al. 1998a, Nakamura et al. 1998b, Troispoux et al. 1999, Marion et al. 2002). With longer term exposure to $\mathrm{FSH}$, Sertoli cells respond by up-regulating phosphodiesterase activity to decrease cAMP levels (Conti et al. 1983) and by down-regulating FSH receptor expression (Themmen et al. 1991). When viewed together, the FSH-mediated activation of phosphodiesterase, the desensitization of the FSH receptor and down-regulation of the receptor as well as the stage-specific control over FSH receptor levels suggests that limiting the timing and duration of FSH signaling is important for Sertoli cell function. In support of this idea, a mouse transgenic model of constitutive FSH action displays elevated testosterone levels and is infertile (Kumar et al. 1999).

\section{Regulation of gene expression by FSH}

The multi-pronged signaling actions of FSH gene expression provide for extensive alterations in the expression of genes in Sertoli cells due to the activation of a number of transcription factors. In addition to the CRE binding factors mentioned previously, FSH stimulation results in translocation of NF- $\mathrm{kB}$ to the nucleus due to the release of NF-кB from its cytoplasmic anchoring partner $I_{\kappa} B$, most likely due to PKA phosphoylating $І к B$ and marking it for degradation (Shirakawa \& Mizel 1989, Ghosh \& Baltimore 1990, Delfino \& Walker 1998). FSH rapidly and transiently induces AP1 activity by stimulating the transcription of the AP1 components $\mathrm{c}$-fos and jun-B while inhibiting c-jun (Hamil et al. 1994). The androgen receptor (AR) is also induced by $\mathrm{FSH}$, thus FSH regulates the androgen responsiveness of Sertoli cells (Verhoven \& Cailleau 1988, Blok et al. 1989, Sanborn et al. 1991, Blok et al. 1992). In granulosa cells, FSH induces LRH-1 (the orphan nuclear receptor liver homologue 1) (Saxena et al. 2004), and HIF-1 (hypoxia inducible factor 1) via the PI3-K pathway (Alam et al. 2004). The potential significance of FSH regulation of LRH-1 and HIF-1 has not yet been investigated in Sertoli cells.

A series of independent studies have identified FSHinducible genes in Sertoli cells that have direct effects in supporting spermatogenesis. These genes include the FSH receptor (Maguire et al. 1997), double sex-and-mab 3 related transcription factor (Dmrt), which has been implicated in sex determination and testis differentiation (Chen \& Heckert 2001), transferrin, which is required to transport iron to germ cells (Suire et al. 1995, Chaudhary \& Skinner 1999), androgen binding protein which may play a role in regulating androgen activity in the testis (Morris et al. 1988) as well as vascular endothelial growth factor (VEGF) (McLean et al. 2002) that may act on receptors present on germ cells from the spermatogonia to round spermatid stages of development (Nalbandian et al. 2003). FSH also up-regulates GDNF (glial cell line derived neurotrophic factor), a member of the TGF$\beta$ superfamily that regulates the proliferation of germinal stem cells (Tadokoro et al. 2002). Additional genes known to be regulated by FSH-inducible cAMP and CREB include lactate dehydrogenase (LDH-A), that controls the synthesis of the major fuel source for germ cells (Short et al. 1994), stem cell factor (kit ligand) that potentiates the survival and expansion of spermatogonia (Taylor et al. 1996), as well as aromatase (Schteingart et al. 1995), plasminogen activator (Nargolwalla et al. 1990) and insulin like growth factor (IGF-I) (Suwanichkul et al. 1993). Recent microarray analyses suggest that at least 300 genes in Sertoli cells are up or down-regulated by FSH (McLean et al. 2002, Sadate-Ngatchou et al. 2004a). Remarkably, the microarray studies identified few new FSH-regulated genes that have known or potential direct influences on germ cell survival or 
development. However, the relative lack of information provided related to spermatogenesis may be due to the less differentiated status of the Sertoli cells used for the studies that were isolated from immature 20 day-old rats or adult hpg mice that both have few germ cells beyond the spermatocyte stage. Further gene expression studies employing mature Sertoli cells will be useful to better understand the results of FSH signaling.

\section{Testosterone signaling}

\section{Testosterone levels and AR expression during Sertoli cell development}

In contrast to $\mathrm{FSH}$, it is well established that androgen is absolutely essential for the maintenance of spermatogenesis (reviewed in Sharpe 1994, McLachlan et al. 2002). Although dihydrotestosterone (DHT) is crucial for the development of the male reproductive tract, testosterone is the androgen in the testis that regulates spermatogenesis. In fetal male rats, serum testosterone levels are elevated beginning 3 to 4 days prior to birth and remain high $(0.5 \mathrm{ng} / \mathrm{ml})$ until 8 days after birth. Testosterone concentrations progressively decrease to about $0.2 \mathrm{ng} / \mathrm{ml}$ during post-natal days 8 to 24 . From days 30 to 55 testosterone levels rise to stable adult levels $(1-2 \mathrm{ng} / \mathrm{ml}$ ) (Ketelslegers et al. 1978). Adult concentrations of intratesticular testosterone in the rat are approximately 50 to 100 -fold higher than that found in serum. Although the physiological advantages of elevated testosterone levels in the testis are not understood, the higher testicular levels of testosterone are important because full spermatogenic capacity requires $70 \mathrm{ng} / \mathrm{ml}$ and spermatogenesis is dramatically compromised at testosterone concentrations below $20 \mathrm{ng} / \mathrm{ml}$ (Zirkin et al. 1989).

In the testis, only Leydig cells, peritubular cells and Sertoli cells express AR. No AR is expressed in germ cells of the mature testis (Lyon et al. 1975). In rat Sertoli cells, the levels of AR are low or below detection until 5 to 10 days after birth but then increase up to 35 or 60 days of age (Buzek \& Sanborn 1988, Bremner et al. 1994, Zhou et al. 1996). Adult AR levels increase and decrease in a cyclical fashion. Specifically, analyses of in situ hybridization and immunocytochemistry results revealed that AR levels progressively increase during cell association stages II through VII of the spermatogenic cycle and then decline sharply

Table 1 Androgen-regulated genes. Three classes of androgen-responsive genes are listed: Androgen-regulated genes in which there is no proof of AR-DNA interactions, Androgen-regulated genes with known AR-DNA interactions and Androgen-regulated genes with known AR-DNA interactions that are expressed in Sertoli cells. The transcriptional response to androgen, activation (A) or repression (R) is noted.

\begin{tabular}{|c|c|c|}
\hline Gene & Antrogen response & Reference \\
\hline \multicolumn{3}{|l|}{ Antrogen-regulated genes } \\
\hline HMAK & A & Xia et al. 2002 \\
\hline SPAK & A & Qi et al. 2001 \\
\hline $\mathrm{FSH}-\beta$ & A & Spady et al. 2004 \\
\hline Fibroblast growth factor $2^{1}$ & A & Rosini et al. 2002 \\
\hline CDK2, CDK4 & A & Lu et al. 1997 \\
\hline p16 & $\mathrm{R}$ & Lu et al. 1997 \\
\hline p27 & A & Chen et al. 1996 \\
\hline AlbZIP & A & Qi et al. 2002 \\
\hline NKX3.1 & A & He et al. 1997 \\
\hline PART-1 & A & Lin et al. 2000 \\
\hline Prostase & A & Nelson et al. 1999 \\
\hline Prostein & A & Xu et al. 2001 \\
\hline Fatty acid synthase & A & Swinnen et al. 1997 \\
\hline c-myc & A & Lim et al. 1994 \\
\hline \multicolumn{3}{|c|}{ Antrogen-regulated genes with known AR-DNA interactions } \\
\hline Prostate specific antigen (PSA) & A & Luke \& Coffey 1994, Sun et al. 1997 \\
\hline Kallikrein 2 (KLK2) & A & Sun et al. 1997, Mitchell et al. 2000 \\
\hline Probasin & A & Rennie et al. 1993, Claessens et al. 2001, Zhang et al. 2004 \\
\hline Tyrosine aminotransferase & A & Denison et al. 1989 \\
\hline p21 & A & Lu et al. 1999 \\
\hline Neutral endopeptidase 24.11 (NEP) & A & Shen et al. 2000 \\
\hline Sex-limited protein (Slp) & A & Verriidt et al. 2000 \\
\hline Ventral prostate $\mathrm{C}^{2}$ & A & Tan et al. 1992, Claessens et al. 1993 \\
\hline Androgen receptor ${ }^{3}$ & A & Grad et al. 1999 \\
\hline Glycoprotein hormone $\alpha$ sununit $^{4}$ & $\mathrm{R}$ & Jorgensen \& Nilson 2001 \\
\hline \multicolumn{3}{|c|}{ Androgen-regulated genes with known AR-DNA interactions on Sertoli cells } \\
\hline Pem & A & Lindsey \& Wilkinson 1996 \\
\hline
\end{tabular}

${ }^{1}$ FGF2 is activated by AR but no binding data is available.

${ }^{2} \mathrm{AR}$ binds to the first intron of $\mathrm{C} 3$.

${ }^{3}$ AR binds to AREs in exons of the AR gene.

${ }^{4}$ AR down-regulates not by binding DNA but by interacting with c-jun and AP2 to inhibit their binding to DNA. 
during or immediately after stage VII to become barely detectable in stages IX-XIII (Bremner et al. 1994, Vornberger et al. 1994, Shan et al. 1995). The levels of androgen receptor are highest in stage VII and thus this stage is thought to be the most regulated by and sensitive to testosterone (Kerr et al. 1993). From various models in which testosterone is withdrawn from rats, it has been confirmed that in the absence of testosterone, progressive germ cell degeneration begins during stage VII of the spermatogenic cycle (reviewed in Sharpe 1994).

\section{Testosterone signaling: the classical mechanism}

The classical mechanism by which androgens and other steroid hormones exert their effects is initiated with the diffusion of the hormone into a target cell through the plasma membrane. The hormones then bind with high affinity to specific intracellular receptor proteins that are present in the cytoplasm and/or nucleus. The binding of the steroid to its receptor produces conformational changes that result in the formation of a "transformed" or activated receptor that has high affinity for specific DNA-binding sites (Tsai \& O'Malley 1994). Once the steroid-receptor complex is formed, it acts as a ligand-inducible transcription factor that is able to recruit coactivator proteins and stimulate gene transcription (Bagchi et al. 1992). The entire process required to initiate gene expression via this classical mechanism takes at least 30-45 min (Shang et al. 2000, Shang et al. 2002), and the length of time required to produce significant levels of nascent proteins is in the order of hours.

\section{Testosterone regulation of gene expression}

Recently, microarray analyses were performed using testis tissue from hpg mice that lack germ cells but contain the somatic cells expressing AR. Although cell-specific information was not produced, 4, 8 and $12 \mathrm{~h}$ after injection these studies identified 56, 129 and 48 genes, respectively, that were regulated by testosterone. Interestingly, within these relatively brief incubation periods, more genes were down-regulated than up-regulated by about a 2:1 ratio. In contrast, of the 234 genes regulated by testosterone after $24 \mathrm{~h}$, approximately 2 genes were up-regulated for every down-regulated gene. As was the case for $\mathrm{FSH}$ regulated genes, microarray analysis identified few genes that had known or potential direct roles in regulating spermatogenesis (Sadate-Ngatchou et al. 2004b).

Although many genes can be regulated by androgens, relatively few are known to be regulated by androgen receptor binding to androgen response elements in promoters and fewer yet have been proved to be regulated by this classical mechanism in Sertoli cells (Table 1). In fact, only the gene that encodes the Pem transcription factor is known to be induced by AR-DNA interactions in Sertoli cells (Lindsey \& Wilkinson 1996). Thus, based on this limited knowledge of testosterone-regulation of gene expression in Sertoli cells, it is not clear how testosterone acts via gene regulatory mechanisms to support spermatogenesis (see 'The testosterone paradox' below).

\section{Testosterone elevates intracellular $\mathrm{Ca}^{2+}$ levels in Sertoli cells}

In addition to known classical actions of testosterone in mediating AR-regulated transcription, androgen (but not other steroids) elevates intracellular $\mathrm{Ca}^{2+}$ concentration $\left(\left[\mathrm{Ca}^{2+}\right]_{\mathrm{i}}\right)$ in freshly isolated, suspension cultures of Sertoli cells within seconds of stimulation (Gorczynska \& Handelsman 1995, Lyng et al. 2000). In Sertoli cells, testosterone-mediated elevation of $\left[\mathrm{Ca}^{2+}\right]_{i}$ required the influx of extracellular $\mathrm{Ca}^{2+}$, suggesting that calcium channels in the plasma membrane play a role in testosterone-calcium signaling (Lyng et al. 2000). Sertoli cells express at least 4 types of voltage sensitive calcium channels (VSCC) in the plasma membrane ( $\mathrm{L}, \mathrm{N}, \mathrm{P} / \mathrm{Q}$ and $\mathrm{T}$ types) (D'Agostino et al. 1992, Fragale et al. 2000). However, L-type channels have been implicated as the major conveyers of testosterone-induced $\mathrm{Ca}^{2+}$ into Sertoli cells. (Lyng et al. 2000). Testosterone linked to BSA, which is unable to pass through the plasma membrane, also induced $\mathrm{Ca}^{2+}$ influx suggesting that testosterone actions may be mediated directly at the membrane (Gorczynska \& Handelsman 1995). Unlike FSH that elevates intracellular $\mathrm{Ca}^{2+}$ via a cAMP-dependent mechanism, testosterone does not increase cAMP levels in Sertoli cells (Gorczynska \& Handelsman 1995, Fix et al. 2004). Even though the signaling pathways resulting in elevated $\left[\mathrm{Ca}^{2+}\right]_{i}$ would appear to be different, FSH and testosterone effects on intracellular $\mathrm{Ca}^{2+}$ are not additive (Gorczynska \& Handelsman 1995). This result suggests that FSH and testosterone may act on similar $\mathrm{Ca}^{2+}$ channels.

It has been proposed that $\mathrm{Ca}^{2+}$-dependent actions of androgen in Sertoli cells involve the closing of an ATPdependent $\mathrm{K}^{+}$channel because testosterone-mediated increases in $\left[\mathrm{Ca}^{2+}\right]_{\mathrm{i}}$ were nullified by the $\mathrm{K}^{+}$channel agonist diazoxide (Silva et al. 2002). This finding raises the possibility that depolarization of Sertoli cells due to testosterone closing of $\mathrm{K}^{+}$-ATP channels is the mechanism that causes $\mathrm{Ca}^{2+}$ uptake through L-type voltage dependent $\mathrm{Ca}^{2+}$ channels. An alternative possibility is that androgens may open $\mathrm{K}^{+}$channels in Sertoli cells as testosterone and DHT reportedly contribute to vasodilation by opening a large conductance, calcium- and voltage-activated $\mathrm{K}^{+}$ channel in coronary myocytes (Deenadayalu et al. 2001).

\section{The testosterone paradox}

Testosterone actions present an interesting paradox in that numerous genes and proteins are up-regulated in response to stimulation but few genes have been characterized that are known to be induced with this steroid through the classical mechanism of AR binding to specific promoter elements. At least two observations support the hypothesis 
that testosterone may act through alternative mechanisms to complement classical AR actions in Sertoli cells. First, Sertoli cells require testicular testosterone levels greater than $70 \mathrm{nM}$ to support full spermatogenesis even though testosterone binding to $\mathrm{AR}$ and gene expression responses to testosterone are saturated at $1 \mathrm{nM}$ (Rommerts 1988, Zirkin et al. 1989, Veldscholte et al. 1992, Sharpe 1994). Second, $\left[\mathrm{Ca}^{2+}\right]_{\mathrm{i}}$ levels are elevated in primary Sertoli cells within seconds of androgen stimulation and thus cannot be dependent on AR-DNA interactions and initiation of gene expression (Steinsapir et al. 1991, Gorczynska \& Handelsman 1995, Lyng et al. 2000). Together, these observations suggest that testosterone acts in Sertoli cells through pathways in addition to classical mechanisms to regulate spermatogenesis.

\section{Testosterone activates MAP kinase and the CREB transcription factor in Sertoli cells}

Increasing evidence has been gathered demonstrating that androgen can directly activate cellular signaling pathways by nongenomic pathways that are independent of $A R$ binding to DNA (reviewed in Cato et al. 2002, Heinlein \& Chang 2002, Silva et al. 2002). Particularly relevant is the activation of the MAP kinase pathway by androgens. In other cell types, androgen can induce a number of factors that have been implicated in regulating the MAP kinase cascade including PKA, calmodulin, phospholipase C, protein kinase $\mathrm{C}$ and guanine nucleotide exchange factors (GEFs) (Finkbeiner \& Greenberg 1996). All these factors have been found to be capable of initiating the MAP kinase cascade by stimulating a Ras or a Ras-like protein to activate a Raf MAP kinase kinase kinase (MAPKKK) (Pearson et al. 2001).
Testosterone-mediated activation of MAP kinase was recently characterized in Sertoli cells. Physiological levels of testosterone (10-250nM), but not estradiol or progesterone, rapidly (within $15 \mathrm{~min}$ ) induced the phosphorylation and activation of the Erk MAPK and CREB in Sertoli cells from 15 day-old rats. CREB phosphorylation increased about 3 -fold within 1 to $15 \mathrm{~min}$ and 5 -fold 1 to $2 \mathrm{hrs}$ after stimulation with the non-hydrolizable androgen agonist R1881. Erk phosphorylation followed similar kinetics and the MAP kinase pathway inhibitor PD98059 blocked testosterone-mediated induction of CREB phosphorylation thus supporting the hypothesis that androgen-induced CREB phosphorylation is mediated via the MAP kinase pathway. Further studies have been performed demonstrating that testosterone activates Src kinase in Sertoli cells (Cheng J and Walker WH, unpublished results). A scaffold protein called modulator of nongenomic actions of the estrogen receptor (MNAR) was shown to facilitate the activation of Src kinases and MAPK by androgen as MNAR also forms a complex with AR and Src (Wong et al. 2002, Unni et al. 2004). One result of testosterone-mediated stimulation of the MAP kinase cascasde and CREB was the induction of CREB-mediated transcription. Specifically, testosterone was found to induce the expression of three CREB-regulated genes in Sertoli cells (Fix et al. 2004).

Although other receptors may be involved, three lines of evidence support the hypothesis that AR mediates testosterone-induced Erk and CREB phosphorylation. First, the AR antagonist flutamide inhibited testosteronemediated phosphorylation of CREB. Second, CREB was not phosphorylated in Sertoli cells lacking AR activity after RNA interference knockdown of AR expression.

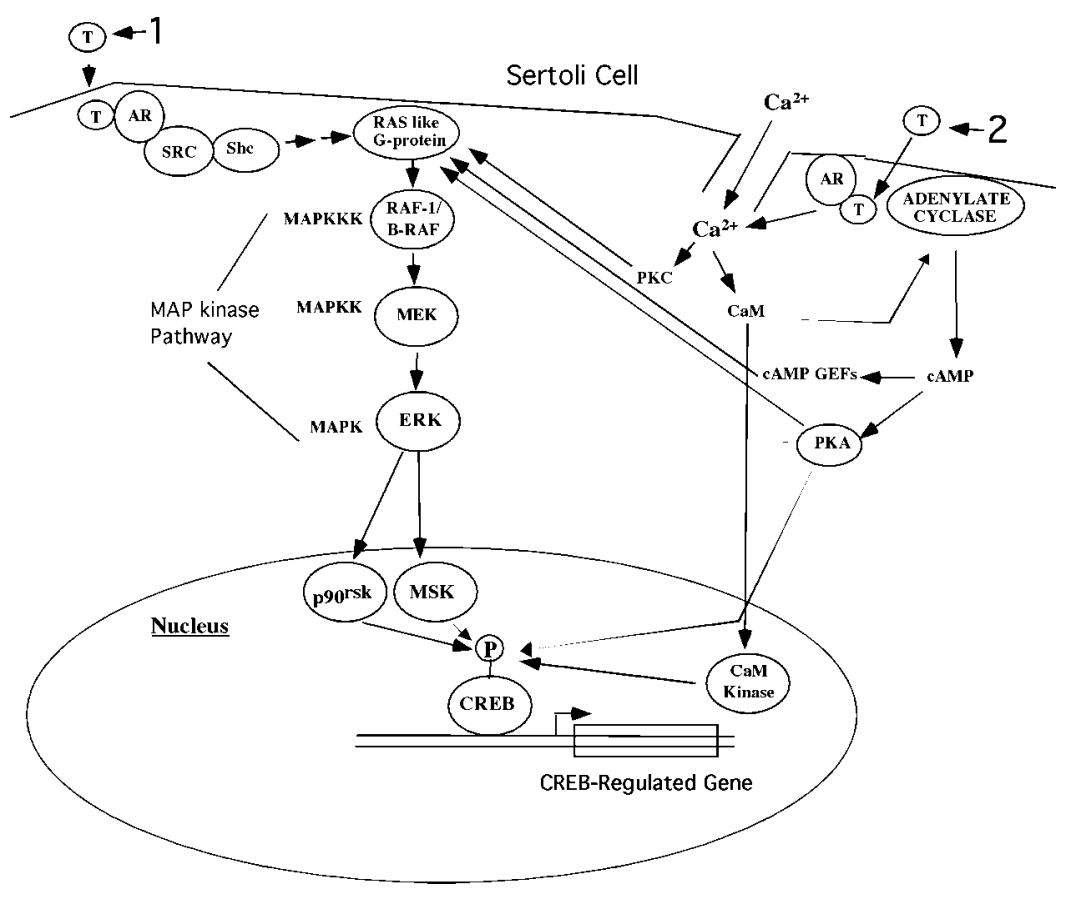

Reproduction (2005) 130 15-28
Figure 2 Potential testosterone signaling pathways in Sertoli cells: Two potential pathways are proposed for testosterone-induced CREB phosphorylation. In one pathway (left side, 1), testosterone $(\mathrm{T})$ binding to AR allows AR to bind with and activate Src tyrosine kinase (SRC) resulting in the stimulation Ras and Raf- 1 kinase and the activation of the MAP kinase pathway. In the second pathway (right side, 2), testosterone induces $\mathrm{Ca}^{2+}$ influx into Sertoli cells that then may cause calmodulin (CaM) to stimulate CaM kinase to translocate to the nucleus and transiently phosphorylate CREB within 1 minute. $\mathrm{Ca}^{2+}$ may also stimulate a slower, more persistent pathway in which protein kinase $\mathrm{C}$ (PKC), guanine nucleotide exchange factors (GEFs) or PKA stimulate Ras or a Ras like GTP binding protein resulting in the activation of the MAP kinase pathway. Both pathways are capable of inducing CREB phosphorylation and CREBmediated gene expression. 
Third, testosterone could not increase CREB phosphorylation in Sertoli cells containing the testicular feminization (tfm) AR mutant that displays dramatically decreased androgen binding capacity (Fix et al. 2004).

Two models were devised to explain how testosterone may activate MAP kinase, CREB phosphorylation and CREB-mediated transcription in Sertoli cells (Fig. 2). In the first pathway, testosterone binds to AR causing the recruitment and activation of Src, thereby initiating a series of events leading to the activation of the MAP kinase cascade by the Ras G-protein. In the second pathway, testosterone binding to AR causes an increase in $\left[\mathrm{Ca}^{2+}\right]_{i}$ that activates numerous potential intermediates that are capable of stimulating Ras or a Ras like G-protein. Results from studies of nonclassical estrogen actions raise the possibility that additional factors may be involved in transmission of androgen signals. Specifically, estrogen-estrogen receptor interactions trigger $G$ protein dependent activation of $\mathrm{Src}$ that then stimulates matrix metalloproteases to release heparin bound epidermal growth factor (HB-EGF) from the surface of the cell. The HB-EGF then binds to the EGF receptor resulting in the activation of the MAP kinase cascade (Razandi et al. 2003).

Regardless of the exact pathway for the nonclassical regulation by testosterone, this newly discovered process is particularly relevant for providing an answer to the paradox of how testosterone can support spermatogenesis yet regulate few genes via AR-promoter interactions. The androgen-induced increases in Src kinase and the MAP kinase cascade that have been characterized thus far have the potential to regulate the expression of many more genes than is possible by direct AR-promoter interactions. Thus, it is likely that nonclassical actions of testosterone in Sertoli cells will be found to be a necessary compliment to the classical actions that are required to maintain spermatogenesis. Determining the factors that are required for testosterone induction of MAP kinase and CREB activity in Sertoli cells will be essential to better understand testosterone regulation of spermatogenesis and androgen regulation of other target tissues.

\section{Integration of the $\mathrm{FSH}$ and testosterone signaling pathways}

FSH and testosterone both initiate signaling pathways that contribute to the support of spermatogenesis and the hormones share some common characteristics. For example, FSH or testosterone can independently support Sertoli cell proliferation although FSH is apparently more effective (Griswold et al. 1977, Meachem et al. 1996, Haywood et al. 2003, Allan et al. 2004, Johnston et al. 2004). Stimulation of Sertoli cell proliferation may be due to the shared ability of FSH and testosterone to activate the MAP kinase pathway in pubertal Sertoli cells. FSH and testosterone induce phosphorylation of ERK kinase to similar levels but FSH is about 2-fold more effective in phosphorylating
CREB (Fix et al. 2004), suggesting that other factors in addition to the MAP kinase pathway may be responsible for more efficient FSH-mediated Sertoli cell proliferation. Because phoshorylated CREB in Sertoli cells was shown to be essential for spermatocyte survival (Scobey et al. 2001), the less efficient phosphorylation of CREB in the presence of testosterone alone may be one contributing factor responsible for the reduced fertility observed with androgens in the absence of FSH. For full fertility, it may also be necessary for CREB to be phosphorylated during specific stages of the spermatogenetic cycle, a condition that may be better controlled with the cyclical up-regulation of the $\mathrm{FSH}$ receptor and cAMP production (Kangasniemi et al. 1990). FSH was only found to activate MAP kinase in pubertal rat Sertoli cells 5 and 11 days after birth but not in 19 day-old rats. Thus far, testosterone activation of the MAP kinase pathway has only been tested in Sertoli cells isolated from 15 day-old rats. It remains to be determined whether testosterone can act via MAP kinase to support CREB activation and spermatogenesis in adult rats.

Another characteristic that is shared by FSH and testosterone is the elevation of $\left[\mathrm{Ca}^{2+}\right]_{i}$ levels in Sertoli cells, although the mechanisms by which elevated $\left[\mathrm{Ca}^{2+}\right]_{\mathrm{i}}$ might support spermatogenesis are not yet known. Together, the shared signals that FSH and testosterone transmit likely explain the redundant functions that these hormones display in supporting spermatogenesis.

There are also differences in the actions of FSH and testosterone. These differences may account for the fact that testosterone but not FSH is capable of maintaining spermatogenesis independently. One difference is that testosterone does not up-regulate cAMP production in Sertoli cells. These findings suggest that either elevated cAMP levels are not required for spermatogenesis or that redundant mechanisms are present. Other possible differences between $\mathrm{FSH}$ and testosterone include the regulation of the PI3-K and $\mathrm{PLA}_{2}$ pathways. FSH has been shown to stimulate the $\mathrm{PI}-\mathrm{K}$ and $\mathrm{PLA}_{2}$ signaling pathways but thus far there is no evidence that testosterone affects these signaling mechanisms in Sertoli cells. However, other steroid hormones have been shown to activate the PI3-K and $\mathrm{PLA}_{2}$ pathways in other systems by non-classical mechanisms (Bagowski et al. 2001, Honda et al. 2001, Fiorini et al. 2003). In the future, it is possible that testosterone may be found to also regulate the PI3-K and $\mathrm{PLA}_{2}$ pathways. A final difference between $\mathrm{FSH}$ and testosterone is the up and down regulation of gene expression via AR-DNA interactions that can only be accomplished after testosterone stimulation. Perhaps future studies will identify genes uniquely regulated by testosterone-induced AR-DNA interactions that are required to maintain spermatogenesis. 


\section{Conclusions and future perspectives}

In recent years, the characterization of the signaling pathways regulated by $\mathrm{FSH}$ and testosterone has been an important step toward the understanding of how these hormones support spermatogenesis. For example, with the finding that FSH and testosterone are both capable of activating the MAP kinase pathway and $\mathrm{Ca}^{2+}$ influx, it now seems reasonable that some of the actions of $\mathrm{FSH}$ and testosterone overlap. Nevertheless, many of the mechanisms by which these hormones support spermatogenesis and the required factors that they regulate remain to be fully characterized, especially for testosterone. It is likely that further study of the nonclassical (nongenomic) testosterone signaling will identify additional testosterone-regulated genes and factors that are required to support spermatogenesis. Also, microarray or similar gene expression studies employing mature Sertoli cells in the context of a normal testis with germ cells present will be important for identifying the $\mathrm{FSH}$ and testosterone regulated factors that are required for spermatogenesis. With this information the characterization of the mechanisms by which FSH and testosterone act hopefully will be facilitated.

\section{Acknowledgements}

This research was supported by NIH grant RO1 HD043143 to $\mathrm{WH}$ Walker. The authors declare that there is no conflict of interest that could prejudice the impartiality of this work.

\section{References}

Alam H, Maizels ET, Park Y, Ghaey S, Feiger ZJ, Chandel NS \& Hunzicker-Dunn M 2004 Follicle-stimulating hormone activation of hypoxia-inducible factor-1 by the phosphatidylinositol 3-kinase/AKT/Ras homolog enriched in brain (Rheb)/mammalian target of rapamycin (mTOR) pathway is necessary for induction of select protein markers of follicular differentiation. Journal of Biological Chemistry 279 19431-19440.

Allan CM, Garcia A, Spaliviero J, Zhang FP, Jimenez M, Huhtaniemi I \& Handelsman DJ 2004 Complete Sertoli cell proliferation induced by follicle-stimulating hormone (FSH) independently of luteinizing hormone activity: evidence from genetic models of isolated FSH action. Endocrinology 145 1587-1593.

Bagchi MK, Tsai MJ, O'Malley BW \& Tsai SY 1992 Analysis of the mechanism of steroid hormone receptor-dependent gene activation in cell-free systems. Endocrine Reviews 13 525-535.

Bagowski CP, Myers JW \& Ferrell JE Jr 2001 The classical progesterone receptor associates with p42 MAPK and is involved in phosphatidylinositol 3-kinase signaling in Xenopus oocytes. Journal of Biological Chemistry 276 37708-37714.

Blok LJ, Mackenbach P, Trapman J, Themmen APN, Brinkman AO \& Grootegoed A 1989 Follicle-stimulating hormone regulates androgen receptor mRNA in Sertoli cells. Molecular and Cellular Endocrinology $63267-271$.

Blok LJ, Hoogenbrugge JW, Themmen APN, Baarends WM, Post M \& Grootegoed A 1992 Transient down-regulation of androgen receptor messenger ribonucleic acid (mRNA) Expression in Sertoli cells by follicle-stimulating hormone is followed by up-regulation of androgen receptor mRNA and protein. Endocrinology 131 $1343-1349$.
Bortolussi M, Zanchetta R, Belvedere P \& Colombo L 1990 Sertoli and Leydig cell numbers and gonadotropin receptors in rat testis from birth to puberty. Cell Tissue Research 260 185-191.

Bremner WJ, Millar MR, Sharpe RM \& Saunders PTK 1994 Immunohistochemical localization of androgen receptors in the rat testis: evidence for stage-dependent expression and regulation by androgens. Endocrinology 135 1227-1234.

Buzek SW \& Sanborn BM 1988 Increase in testicular androgen receptor during sexual maturation in the rat. Biology of Reproduction 39 39-49.

Cato AC, Nestl A \& Mink S 2002 Rapid actions of steroid receptors in cellular signaling pathways. Science's Signal Transduction Knowledge Environment RE9.

Chaudhary J \& Skinner MK 1999 E-box and cyclic adenosine monophosphate response elements are both required for follicle-stimulating hormone-induced transferrin promoter activation in Sertoli cells. Endocrinology $1401262-1271$.

Chen JK \& Heckert LL 2001 Dmrt1 expression is regulated by follicle-stimulating hormone and phorbol esters in postnatal Sertoli cells. Endocrinology 142 1167-1178.

Chen Y, Robles AI, Martinez LA, Liu F, Gimenez-Conti IB \& Conti CJ 1996 Expression of G1 cyclins, cyclin-dependent kinases, and cyclin-dependent kinase inhibitors in androgen-induced prostate proliferation in castrated rats. Cell Growth and Differentiation 7 1571-1578.

Chowdhury M \& Steinberger E 1976 Pituitary and plasma levels of gonadotrophins in foetal and newborn male and female rats. Journal of Endocrinology $69381-384$.

Claessens F, Celis L, De Vos P, Peeters B, Heyns W, Verhoeven G \& Rombauts W 1993 Intronic androgen Response elements of prostatic binding protein genes. Biochemical and Biophysical Research Communications 191 688-694.

Claessens F, Verrijdt G, Schoenmakers E, Haelens A, Peeters B, Verhoeven G \& Rombauts W 2001 Selective DNA binding by the androgen receptor as a mechanism for hormone-specific gene regulation. Journal of Steroid Biochemistry and Molecular Biology $7623-30$.

Conti M, Toscano MV, Petrelli L, Geremia R \& Stefanini M 1983 Involvement of phosphodiesterase in the refractoriness of the Sertoli cell. Endocrinology 113 1845-1853.

Cottom J, Salvador LM, Maizels ET, Reierstad S, Park Y, Carr DW, Davare MA, Hell JW, Palmer SS \& Dent P et al. 2003 Follicle-stimulating hormone activates extracellular signal-regulated kinase but not extracellular signal-regulated kinase kinase through a 100kDa phosphotyrosine phosphatase. Journal of Biological Chemistry $2787167-7179$.

Crepieux P, Martinat N, Marion S, Guillou F \& Reiter E 2002 Cellular adhesion of primary Sertoli cells affects responsiveness of the extracellular signal-regulated kinases 1 and 2 to follicle-stimulating hormone but not to epidermal growth factor. Archives of Biochemistry and Biophysics 399 245-250.

Crepieux P, Marion S, Martinat N, Fafeur V, Vern YL, Kerboeuf D, Guillou F \& Reiter E 2001 The ERK-dependent signalling is stagespecifically modulated by FSH, during primary Sertoli cell maturation. Oncogene 20 4696-4709.

D'Agostino A, Mene P \& Stefanini M 1992 Voltage-gated calcium channels in rat Sertoli cells. Biology of Reproduction $\mathbf{4 6}$ 414-418.

Deenadayalu VP, White RE, Stallone JN, Gao X \& Garcia AJ 2001 Testosterone relaxes coronary arteries by opening the large-conductance, calcium-activated potassium channel. American Journal of Physiology: Heart and Circulatory Physiology 281 $\mathrm{H} 1720-\mathrm{H} 1727$.

Delfino FJ \& Walker WH 1998 Stage-specific nuclear expression of NF-кB in mammalian testis. Molecular Endocrinology 12 1696-1707.

Denison SH, Sands A \& Tindall DJ 1989 A tyrosine aminotransferase glucocorticoid response element also mediates androgen enhancement of gene expression. Endocrinology 124 1091-1093. 
Dias JA 2005 Endocrinology: fertility hormone in repose. Nature 433 203-204.

Fan QR \& Hendrickson WA 2005 Structure of human follicle-stimulating hormone in complex with its receptor. Nature 433 269-277.

Finkbeiner S \& Greenberg ME $1996 \mathrm{Ca}(2+)$-dependent routes to Ras: mechanisms for neuronal survival, differentiation, and plasticity? Neuron 16 233-236.

Fiorini S, Ferretti ME, Biondi C, Pavan B, Lunghi L, Paganetto G \& Abelli L 2003 17Beta-eEstradiol stimulates arachidonate release from human amnion-like WISH cells through a rapid mechanism involving a membrane receptor. Endocrinology 144 $3359-3367$

Fix C, Jordan C, Cano P \& Walker WH 2004 Testosterone activates mitogen-activated protein kinase and the cAMP response element binding protein transcription factor in Sertoli cells. PNAS 101 10919-10924.

Foulkes NS, Schlotter F, Pevet P \& Sassone-Corsi P 1993 Pituitary hormone FSH directs the CREM functional switch during spermatogenesis. Nature 362 264-267.

Fragale A, Aguanno S, Kemp M, Reeves M, Price K, Beattie R, Craig P, Volsen S, Sher E \& D'Agostino A 2000 Identification and cellular localisation of voltage-operated calcium channels in immature rat testis. Molecular and Cellular Endocrinology 162 25-33.

Franchi E \& Camatini M 1985 Evidence that a Ca2 + chelator and a calmodulin blocker interfere with the structure of inter-Sertoli junctions. Tissue Cell 17 13-25.

Ghosh S \& Baltimore D 1990 Activation in vitro of NF-kB by phosphorylation of its inhibitor ІкB. Nature 344 678-682.

Goetz TL, Lloyd TL \& Griswold MD 1996 Role of E box and initiator region in the expression of the rat follicle-stimulating hormone receptor (FSHR) gene in testicular Sertoli cells. Journal of Biological Chemistry 271 33317-33324.

Gonzalez-Robayna IJ, Falender AE, Ochsner S, Firestone GL \& Richards JS 2000 Follicle-Stimulating hormone (FSH) stimulates phosphorylation and activation of protein kinase B (PKB/Akt) and serum and glucocorticoid-Induced kinase (Sgk): evidence for $\mathrm{A}$ kinase-independent signaling by FSH in granulosa cells. Molecular Endocrinology 14 1283-1300.

Gorczynska E \& Handelsman DJ 1991 The role of calcium in folliclestimulating hormone signal transduction in Sertoli cells. Journal of Biological Chemistry 266 23739-23744.

Gorczynska E \& Handelsman DJ 1995 Androgens rapidly increase the cytosolic calcium concentration in Sertoli cells. Endocrinology $1362052-2059$

Gorczynska E, Spaliviero J \& Handelsman DJ 1994 The relationship between $3^{\prime}, 5^{\prime}$-cyclic adenosine monophosphate and calcium in mediating follicle-stimulating hormone signal transduction in Sertoli cells. Endocrinology 134 293-300.

Grad JM, Dai JL, Wu S \& Burnstein KL 1999 Multiple androgen response elements and a Myc consensus site in the androgen receptor (AR) coding region are involved in androgen-mediated up-regulation of AR messenger RNA. Molecular Endocrinology 13 1896-1911.

Grasso P \& Reichert LE Jr 1989 Follicle-stimulating hormone receptor-mediated uptake of $45 \mathrm{Ca} 2+$ by proteoliposomes and cultured rat sertoli cells: evidence for involvement of voltage-activated and voltage-independent calcium channels. Endocrinology 125 3029-3036.

Griswold MD 1998 The central role of Sertoli cells in spermatogenesis. Seminars in Cell and Developmental Biology 9 411-416.

Griswold MD, Solari A, Tung PS \& Fritz IB 1977 Stimulation by follicle-stimulating hormone of DNA synthesis and of mitosis in cultured Sertoli cells prepared from testes of immature rats. Molecular and Cellular Endocrinology 7 151-165.

Hamil KG, Conti M, Shimasaki S \& Hall SH 1994 Follicle-stimulating hormone regulation of AP-1: inhibition of c-jun and stimulation of jun-B gene transcription in the rat Sertoli cell. Molecular and Cellular Endocrinology 99 269-277.
Haywood M, Spaliviero J, Jimemez M, King NJ, Handelsman DJ \& Allan CM 2003 Sertoli and germ cell development in hypogonadal (hpg) mice expressing transgenic follicle-stimulating hormone alone or in combination with testosterone. Endocrinology 144 509-517.

He WW, Sciavolino PJ, Wing J, Augustus M, Hudson P, Meissner PS, Curtis RT, Shell BK, Bostwick DG \& Tindall DJ et al. 1997 A novel human prostate-specific, androgen-regulated homeobox gene (NKX3.1) that maps to 8p21, a region frequently deleted in prostate cancer. Genomics 43 69-77.

Heckert LL \& Griswold MD 1991 Expression of follicle-stimulating hormone receptor mRNA in rat testis and Sertoli cells. Molecular Endocrinology 5 670-677.

Heckert LL \& Griswold MD 2002 The expression of the follicle-stimulating hormone receptor in spermatogenesis. Recent Progress in Hormonal Research 57 129-148.

Heckert LL, Daggett MAF \& Chen J 1998 Multiple promoter elements contribute to activity of the follicle-stimulating hormone receptor (FSHR) gene in testicular Sertoli cells. Molecular Endocrinology 12 1499-1512.

Heinlein CA \& Chang C 2002 The roles of androgen receptors and androgen-binding proteins in nongenomic androgen actions. Molecular Endocrinology 16 2181-2187.

Honda K, Shimohama S, Sawada H, Kihara T, Nakamizo T, Shibasaki H \& Akaike A 2001 Nongenomic antiapoptotic signal transduction by estrogen in cultured cortical neurons. Journal of Neuroscience Research 64 466-475.

Jannini EA, Ulisse S, Cecconi S, Cironi L, Colonna R, D'Armiento M, Santoni A \& Cifone MG 1994 Follicle-stimulating hormoneinduced phospholipase A2 activity and eicosanoid generation in rat Sertoli cells. Biology of Reproduction 51 140-145.

Johnston H, Baker PJ, Abel M, Charlton HM, Jackson G, Fleming L, Kumar TR \& O'Shaughnessy PJ 2004 Regulation of Sertoli cell number and activity by follicle-stimulating hormone and androgen during postnatal development in the mouse. Endocrinology 145 318-329.

Jorgensen JS \& Nilson JH 2001 AR suppresses transcription of the alpha glycoprotein hormone subunit gene through protein-protein interactions with clun and activation transcription factor 2 . Molecular Endocrinology 15 1496-1504.

Kangasniemi M, Kaipia A, Mali P, Toppari J, Huhtaniemi I \& Parvinen M 1990 Modulation of basal and FSH-dependent cyclic AMP production in rat seminiferous tubules staged by an improved transillumination technique. The Anatomical Record $\mathbf{2 2 7}$ $62-76$.

Kerr JB, Millar M, Maddocks S \& Sharpe RM 1993 Stage-dependent changes in spermatogenesis and Sertoli cells in relation to the onset of spermatogenic failure following withdrawal of testosterone. The Anatomical Record 235 547-559.

Ketelslegers JM, Hetzel WD, Sherins RJ \& Catt KJ 1978 Developmental changes in testicular gonadotropin receptors: plasma gonadotropins and plasma testosterone in the rat. Endocrinology 103 212-222.

Kumar TR, Palapattu G, Wang P, Woodruff TK, Boime I, Byrne MC \& Matzuk MM 1999 Transgenic models to study gonadotropin function: the role of follicle-stimulating hormone in gonadal growth and tumorigenesis. Molecular Endocrinology 13 851-865.

Lalevee N, Pluciennik F \& Joffre M 1997 Voltage dependent calcium current with properties of T-type current in Sertoli cells from immature rat testis in primary cultures. Biology of Reproduction $\mathbf{5 6}$ 680-687.

Lin B, White JT, Ferguson C, Bumgarner R, Friedman C, Trask B, Ellis W, Lange P, Hood L \& Nelson PS 2000 PART-1: a novel human prostate-specific, androgen-regulated gene that maps to chromosome 5q12. Cancer Research 60 858-863.

Lindsey JS \& Wilkinson MF 1996 Pem: a testosterone- and LH-regulated homeobox gene expressed in mouse Sertoli cells and epididymus. Developmental Biology 179 471-484. 
Lu S, Tsai SY \& Tsai MJ 1997 Regulation of androgen-dependent prostatic cancer cell growth: androgen regulation of CDK2, CDK4, and CKI p16 genes. Cancer Research 57 4511-4516.

Lu S, Liu M, Epner DE, Tsai SY \& Tsai MJ 1999 Androgen regulation of the cyclin-dependent kinase inhibitor p21 gene through an androgen response element in the proximal promoter. Molecular Endocrinology 13 376-384.

Luke MC \& Coffey DS 1994 Human androgen receptor binding to the androgen Response element of prostate specific antigen. Journal of Andrology 15 41-51.

Lyng FM, Jones GR \& Rommerts FFG 2000 Rapid androgen actions on calcium signaling in rat Sertoli cells and two human prostatic cell lines: Similar biphasic responses between 1 picomolar and 100 nanomolar concentrations. Biology of Reproduction 63 $736-747$

Lyon MF, Glenister PH \& Lamoreux ML 1975 Normal spermatozoa from androgen-resistant germ cells of chimaeric mice and the role of androgen in spermatogenesis. Nature 258 620-622.

Maguire SM, Tribley WA \& Griswold MD 1997 Follicle-stimulating hormone $(\mathrm{FSH})$ regulates the expression of FSH receptor messenger ribonucleic acid in cultured Sertoli cells and in hypophysectomized rat testis. Biology of Reproduction 56 1106-1111.

Maizels ET, Cottom J, Jones JC \& Hunzicker-Dunn M 1998 Follicle stimulating hormone (FSH) activates the p38 mitogen-activated protein kinase pathway, inducing small heat shock protein phosphorylation and cell rounding in immature rat ovarian granulosa cells. Endocrinology $1393353-3356$.

Marion S, Robert F, Crepieux P, Martinat N, Troispoux C, Guillou F \& Reiter E 2002 G protein-coupled receptor kinases and beta arrestins are relocalized and attenuate cyclic 3',5'-adenosine monophosphate Response to follicle-stimulating hormone in rat primary Sertoli cells. Biology of Reproduction 66 70-76.

McLachlan RI, O'Donnell L, Meachem SJ, Stanton PG, De Kretser DM, Pratis K \& Robertson DM 2002 Identification of specific sites of hormonal regulation in spermatogenesis in rats, monkeys, and man. Recent Progress in Hormonal Research 57 149-179.

McLean DJ, Friel PJ, Pouchnik D \& Griswold MD 2002 Oligonucleotide microarray analysis of gene Expression in follicle-stimulating hormone-treated rat Sertoli cells. Molecular Endocrinology 16 2780-2792.

Meachem SJ, McLachlan RI, de Kretser DM, Robertson DM \& Wreford NG 1996 Neonatal exposure of rats to recombinant follicle stimulating hormone increases adult Sertoli and spermatogenic cell numbers. Biology of Reproduction 54 36-44.

Meroni SB, Riera MF, Pellizzari EH \& Cigorraga SB 2002 Regulation of rat Sertoli cell function by FSH: possible role of phosphatidylinositol 3-kinase/protein kinase B pathway. Journal of Endocrinology 174 195-204.

Mitchell SH, Murtha PE, Zhang S, Zhu W \& Young CY 2000 An androgen Response element mediates LNCaP cell dependent androgen induction of the hK2 gene. Molecular and Cellular Endocrinology 168 89-99.

Molina CA, Foulkes NS, Lalli E \& Sassone-Corsi P 1993 Inducibility and negative autoregulation of CREM: An alternative promoter directs the expression of ICER, an early response repressor. Cell 75 875-886.

Morris PL, Vale WW, Cappel S \& Bardin CW 1988 Inhibin production by primary Sertoli cell-enriched cultures: regulation by follicle-stimulating hormone, androgens, and epidermal growth factor. Endocrinology 122 717-725.

Mruk DD \& Cheng CY 2004 Sertoli-Sertoli and Sertoli-germ cell interactions and their significance in germ cell movement in the seminiferous epithelium during spermatogenesis. Endocrine Reviews 25 747-806.

Nakamura K, Hipkin RW \& Ascoli M 1998a The agonist-induced phosphorylation of the rat follitropin receptor maps to the first and third intracellular loops. Molecular Endocrinology 12 580-591.

Nakamura K, Krupnick JG, Benovic JL \& Ascoli M 1998b Signaling and phosphorylation-impaired mutants of the rat follitropin receptor reveal an activation- and phosphorylation-independent but arrestin-dependent pathway for internalization. Journal of Biological Chemistry $27324346-24354$.

Nalbandian A, Dettin L, Dym M \& Ravindranath N 2003 Expression of vascular endothelial growth factor receptors during male germ cell differentiation in the mouse. Biology of Reproduction 69 985-994.

Nantel F, Monoco L, Foulkes NS, Masquillier D, LeMeur M, Henriksen K, Dierich M, Parvinen M \& Sassone-Corsi P 1996 Spermiogenesis deficiency and germ cell apoptosis in CREM-mutant mice. Nature 380 159-162.

Nargolwalla C, McCabe D \& Fritz IB 1990 Modulation of levels of messenger RNA for tissue-type plasminogen activator in rat Sertoli cells, and levels of messenger RNA for plasminogen activator inhibitor in testis peritubular cells. Molecular and Cellular Endocrinology 70 73-80.

Nechamen CA, Thomas RM, Cohen BD, Acevedo G, Poulikakos PI, Testa JR \& Dias JA 2004 Human follicle-stimulating hormone (FSH) receptor interacts with the adaptor protein APPL1 in HEK 293 cells: potential involvement of the PI3K pathway in FSH signaling. Biology of Reproduction 71 629-636.

Nelson PS, Gan L, Ferguson C, Moss P, Gelinas R, Hood L \& Wang K 1999 Molecular cloning and characterization of prostase, an androgen-regulated serine protease with prostate-restricted expression. PNAS 96 3114-3119.

Orth JM 1984 The role of follicle-stimulating hormone in controlling Sertoli cell proliferation. Endocrinology 115 1248-1255.

Orth JM, Gunsalus GL \& Lamperti AA 1988 Evidence from Sertoli cell-depleted rats indicates that spermatid number in adults depends on numbers of Sertoli cells produced during perinatal development. Endocrinology 122 787-794.

Pearson G, Robinson F, Gibson TB, Xu B-E, Karandikar M, Berman K \& Cobb MH 2001 Mitogen-activated protein (MAP) kinase pathways: regulation and physiological functions. Endocrine Reviews 22 153-183.

Qi H, Labrie Y, Grenier J, Fournier A, Fillion C \& Labrie C 2001 Androgens induce Expression of SPAK, a STE20/SPS1-related kinase, in LNCaP human prostate cancer cells. Molecular and Cellular Endocrinology 182 181-192.

Qi H, Fillion C, Labrie Y, Grenier J, Fournier A, Berger L, El-Alfy M \& Labrie C 2002 AlbZIP, a novel bZIP gene located on chromosome $1 \mathrm{q} 21.3$ that is highly expressed in prostate tumors and of which the expression is up-regulated by androgens in LNCaP human prostate cancer cells. Cancer Research 62 721-733.

Razandi M, Pedram A, Park ST \& Levin ER 2003 Proximal events in signaling by plasma membrane estrogen receptors. Journal of Biological Chemistry 278 2701-2712.

Rennie PS, Bruchovsky N, Leco KJ, Sheppard PC, McQueen SA, Cheng $H$, Snoek R, Hamel A, Bock ME \& MacDonald BS et al. 1993 Characterization of two cis-acting DNA elements involved in the androgen regulation of the probasin gene. Molecular Endocrinology $723-36$

Rommerts FFG 1988 How much androgen is required for maintenance of spermatogenesis? Journal of Endocrinology 116 7-9.

Rosini P, Bonaccorsi L, Baldi E, Chiasserini C, Forti G, De Chiara G, Lucibello M, Mongiat M, Iozzo RV \& Garaci E et al. 2002 Androgen receptor expression induces FGF2, FGF-binding protein production, and FGF2 release in prostate carcinoma cells: role of FGF2 in growth, survival, and androgen receptor down-modulation. Prostate 53 310-321.

Sadate-Ngatchou PI, Pouchnik DJ \& Griswold MD 2004a Folliclestimulating hormone induced changes in gene Expression of murine testis. Molecular Endocrinology 18 2805-2816.

Sadate-Ngatchou PI, Pouchnik DJ \& Griswold MD 2004b Identification of testosterone-regulated genes in testes of hypogonadal mice using oligonucleotide microarray. Molecular Endocrinology $18422-433$. 
Sanborn BM, Caston LA, Chang C, Liao S, Speller R, Porter LD \& Ku CY 1991 Regulation of androgen receptor mRNA in rat Sertoli and peritubular cells. Biology of Reproduction 45 634-641.

Saxena D, Safi R, Little-Ihrig L \& Zeleznik AJ 2004 Liver receptor homolog-1 stimulates the progesterone biosynthetic pathway during follicle-stimulating hormone-induced granulosa cell differentiation. Endocrinology 145 3821-3829.

Schteingart HF, Meroni SB, Pellizzari EH, Perez AL \& Cigorraga SB 1995 Regulation of Sertoli cell aromatase activity by cell density and prolonged stimulation with FSH, EGF, insulin and IGF-I at different moments of pubertal development. Journal of Steroid Biochemistry and Molecular Biology 52 375-381.

Scobey MJ, Bertera S, Somers JP, Watkins SC, Zeleznik AJ \& Walker WH 2001 Delivery of a cyclic adenosine 3', 5'-monophosphate Response element binding protein (CREB) to seminiferous tubules results in impaired spermatogenesis. Endocrinology 142 948-954.

Scobey MJ, Fix CA \& Walker WH 2004 The Id2 transcriptional repressor is induced by follicle-stimulating hormone and cAMP. Journal of Biological Chemistry 279 16064-16070.

Shan L-X, KZhu L-J, Bardin CW \& Hardy MP 1995 Quantitative analysis of androgen receptor messenger ribonucleic acid in developing Leydig cells and Sertoli cells by in situ hybridization. Endocrinology 136 3856-3862.

Shang Y, Hu X, DiRenzo J, Lazar MA \& Brown M 2000 Cofactor dynamics and sufficiency in estrogen receptor-regulated transcription. Cell 103 843-852.

Shang Y, Myers M \& Brown M 2002 Formation of the androgen receptor transcription complex. Molecular Cell 9 601-610.

Sharma OP, Flores JA, Leong DA \& Veldhuis JD 1994 Cellular basis for follicle-stimulating hormone-stimulated calcium signaling in single rat Sertoli cells: possible dissociation from effects of adenosine 3',5'-monophosphate. Endocrinology 134 1915-1923.

Sharpe RM 1994 Regulation of spermatogenesis. In The Physiology of Reproduction, pp 1363-1434. Eds E Knobil \& JD Neil. New York: Raven Press.

Shen R, Sumitomo M, Dai J, Hardy DO, Navarro D, Usmani B, Papandreou CN, Hersh LB, Shipp MA \& Freedman LP et al. 2000 Identification and characterization of two androgen response regions in the human neutral endopeptidase gene. Molecular and Cellular Endocrinology 170 131-142.

Shirakawa F \& Mizel S 1989 In vitro activation and nuclear translocation of NF- $\mathrm{kB}$ catalyzed cyclic AMP-dependent protein kinase and protein kinase C. Molecular Cell Biology 9 2424-2430.

Short ML, Huang D, Milkowski DM, Short S, Kunstman K, Soong CJ, Chung KC \& Jungmann RA 1994 Analysis of the rat lactate dehydrogenase A subunit gene promoter/regulatory region. Biochemical Journal 304 391-398.

Silva FRMB, Leite LD \& Wassermann GF 2002 Rapid signal transduction in Sertoli cells. European Journal of Endocrinology 147 425-433.

Simoni M, Gromoli J \& Niesclag E 1997 The follicle-stimulating hormone receptor: biochemistry, molecular biology, physiology, and pathophysiology. Endocrine Reviews 18 739-773.

Skinner MK 2005 Sertoli cell secreted regulatory factors. In Sertoli Cell Biology, pp 107-120. Eds MK Skinner \& MD Griswold. San Diego: Elsevier Science.

Spady TJ, Shayya R, Thackray VG, Ehrensberger L, Bailey JS \& Mellon PL 2004 Androgen regulates follicle-stimulating hormone beta gene Expression in an activin-dependent manner in immortalized gonadotropes. Molecular Endocrinology 18 925-940.

Spruill WA, Zysk JR, Tres LL \& Kierszenbaum AL 1983 Calcium/calmodulin-dependent phosphorylation of vimentin in rat sertoli cells. PNAS 80 760-764.

Steinsapir J, Socci R \& Reinach P 1991 Effects of androgen on intracellular calcium of LNCaP cells. Biochemical and Biophysical Research Communications 179 90-96.

Suire S, Fontaine I \& Guillou F 1995 Follicle stimulating hormone (FSH) stimulates transferrin gene transcription in rat Sertoli cells: cis and trans-acting elements involved in FSH action via cyclic adenosine $3^{\prime}, 5^{\prime}$-monophosphate on the transferrin gene. Molecular Endocrinology. 9 756-766.

Sun Z, Pan J \& Balk SP 1997 Androgen receptor-associated protein complex binds upstream of the androgen-responsive elements in the promoters of human prostate-specific antigen and kallikrein 2 genes. Nucleic Acids Research 25 3318-3325.

Suwanichkul A, DePaolis LA, Lee PD \& Powell DR 1993 Identification of a promoter element which participates in cAMP-stimulated expression of human insulin-like growth factorbinding protein-1. Journal of Biological Chemistry 268 9730-9736.

Swinnen JV, Esquenet M, Goossens K, Heyns W \& Verhoeven G 1997 Androgens stimulate fatty acid synthase in the human prostate cancer cell line LNCaP. Cancer Research 57 1086-1090.

Tadokoro Y, Yomogida K, Ohta H, Tohda A \& Nishimune Y 2002 Homeostatic regulation of germinal stem cell proliferation by the GDNF/FSH pathway. Mechinisms of Development 113 29-39.

Tan J, Marschke KB, Ho KC, Perry ST, Wilson EM \& French FS 1992 Response elements of the androgen-regulated C3 gene. Journal of Biological Chemistry 267 4456-4466.

Taylor WE, Najmabadi H, Strathearn M, Jou NT, Liebling M, Rajavashisth T, Chanani N, Phung L \& Bhasin S 1996 Human stem cell factor promoter deoxyribonucleic acid sequence and regulation by cyclic 3', 5'-adenosine monophosphate in a Sertoli cell line. Endocrinology 137 5407-5414.

Themmen APN, Blok LJ, Post M, Baarends WM, Hoogerbrugge JW, Vassart G, Anton J \& Grootengoed JA 1991 Follitropin receptor down-regulation involves a CAMP-dependent post-transcriptional decrease of receptor mRNA Expression. Molecular and Cellular Endocinology 78 R7-R13.

Troispoux C, Guillou F, Elalouf JM, Firsov D, lacovelli L, De Blasi A Combarnous Y \& Reiter E 1999 Involvement of G protein-coupled receptor kinases and arrestins in desensitization to follicle-stimulating hormone action. Molecular Endocrinology 13 1599-1614.

Tsai MJ \& O'Malley BW 1994 Molecular mechanisms of action of steroid/thyroid receptor superfamily members. Annual Reviews of Biochemistry 63 451-486.

Unni E, Sun S, Nan B, McPhaul MJ, Cheskis B, Mancini MA \& Marcelli M 2004 Changes in androgen receptor nongenotropic signaling correlate with transition of LNCaP cells to androgen independence. Cancer Research 64 7156-7168.

Veldscholte J, Berrevoets CA, Ris-Stalpers C, Kuiper GG, Jenster G, Trapman J, Brinkmann AO \& Mulder E 1992 The androgen receptor in LNCaP cells contains a mutation in the ligand binding domain which affects steroid binding characteristics and Response to antiandrogens. Journal of Steroid Biochemistry and Molecular Biology 41 665-669.

Verhoeven G, Cailleau J \& de Moor P 1980 Desensitization of cultured rat Sertoli cells by follicle-stimulating hormone and by L-isoproterenol. Molecular and Cellular Endocrinology 20 113-126.

Verhoven G \& Cailleau J 1988 Follicle-stimulating hormone and androgens increase the concentration of the androgen receptor in Sertoli cells. Endocrinology 122 1541-1550.

Verrijdt G, Schoenmakers E, Haelens A, Peeters B, Verhoeven G, Rombauts W \& Claessens F 2000 Change of specificity mutations in androgen-selective enhancers. Evidence for a role of differential DNA binding by the androgen receptor. Journal of Biological Chemistry 275 12298-12305.

Vornberger W, Prins G, Musto NA \& Suarez-Quian CA 1994 Androgen receptor distribution in rat testis: new implications for androgen regulation of spermatogenesis. Endocrinology 134 2307-2316.

Walker WH \& Habener JF 1996 Role of transcription factors CREB and CREM in CAMP-regulated transcription during spermatogenesis. Trends in Endocrinology and Metabolism 7 133-138.

Walker WH, Fucci L \& Habener JF 1995 Expression of the gene encoding transcription factor adenosine $3^{\prime}, 5^{\prime}$-monophosphate (cAMP) Response element-binding protein: regulation by 
follicle-stimulating hormone-induced cAMP signaling in primary rat Sertoli cells. Endocrinology 136 3534-3545.

Walker WH, Daniel PB \& Habener JF 1998 Inducible cAMP early repressor ICER down-regulation of CREB gene Expression in Sertoli cells. Molecular and Cellular Endocrinology 143 167-178.

Warren DW, Huhtaniemi IT, Tapanainen J, Dufau ML \& Catt KJ 1984 Ontogeny of gonadotropin receptors in the fetal and neonatal rat testis. Endocrinology 114 470-476.

Wong CW, McNally C, Nickbarg E, Komm BS \& Cheskis BJ 2002 Estrogen receptor-interacting protein that modulates its nongenomic activity-crosstalk with Src/Erk phosphorylation cascade. PNAS 99 14783-14788.

Wu G-Y, Deisseroth K \& Tsien RW 2001 Activity-dependent CREB phosphorylation: Convergence of a fast, sensitive calmodulin kinase pathway and a slow, less sensitive mitogen-activated protein kinase pathway. PNAS 98 2808-2813.

Xia L, Robinson D, Ma AH, Chen HC, Wu F, Qiu Y \& Kung HJ 2002 Identification of human male germ cell-associated kinase, a kinase transcriptionally activated by androgen in prostate cancer cells. Journal of Biological Chemistry 277 35422-35433.

Xu J, Kalos M, Stolk JA, Zasloff EJ, Zhang X, Houghton RL, Filho AM, Nolasco M, Badaro R \& Reed SG 2001 Identification and characterization of prostein, a novel prostate-specific protein. Cancer Research 61 1563-1568.
Zhang J, Gao N, Kasper S, Reid K, Nelson C \& Matusik RJ 2004 An androgen-dependent upstream enhancer is essential for high levels of probasin gene expression. Endocrinology 145 134-148.

Zhang SB, Dattatreyamurty B \& Reichert LE Jr 1991 Differential roles of high and low affinity guanosine $5^{\prime}$-triphosphate binding sites in the regulation of follicle-stimulating hormone binding to receptor and signal transduction in bovine calf testis membranes. Endocrinology 128 295-302.

Zhou X, Kudo A, Kawakami H \& Hirano H 1996 Immunohistochemical localization of androgen receptor in mouse testicular germ cells during fetal and postnatal development. The Anatomical Record 245 509-518.

Zirkin BR, Santulli R, Awoniyi CA \& Ewing LL 1989 Maintenance of advanced spermatogenic cells in the adult rat testis: quantitative relationship to testosterone concentration within the testis. Endocrinology $1243043-3049$.

Received 17 February 2005

First decision 18 April 2005

Revised manuscript received 27 April 2005

Accepted 3 May 2005 